\title{
IFN $\gamma+$ Treg in-vivo and in-vitro represent both activated nTreg and peripherally induced aTreg and remain phenotypically stable in-vitro after removal of the stimulus
}

Volker Daniel, Karina Trojan, Martina Adamek and Gerhard Opelz

\begin{abstract}
Background: IFNy-producing CD4+CD25+Foxp3+CD127- Treg represent the first line of Treg during an immune response. In the present study we determined whether IFNy+ Treg in-vivo and in-vitro are Helios-positive representing activated natural (nTreg) or Helios-negative representing adaptive Treg (aTreg) and whether they originate from CD4 $+C D 25+$ and/or CD4+CD25- PBL. Furtheron, we investigated whether they are inducible by recombinant IFNy (rIFNץ) as a single stimulus, decrease in-vitro after elimination of the stimulus, and have a demethylated Foxp3 Treg-specific demethylated region (TSDR) which is associated with stable Foxp3 expression.
\end{abstract}

Method: Subsets of IFNY+ Treg were determined in peripheral blood of healthy controls using eight-color flow cytometry and were further investigated in-vitro. Foxp3 TSDR methylation status was determined using bisulphite polymerase chain reaction (PCR) and high resolution melt (HRM) analysis.

Results: Nearly all Treg in the peripheral blood were Helios+IFNY- $(1.9 \pm 1.1 / \mu$ l) and only few were Helios+IFNy+ or Helios-IFNy+ Treg (both $0.1 \pm 0.1 / \mu \mathrm{l})$. Enriched IFNy+ Treg subsets showed in part strong Foxp3 TSDR demethylation. In-vitro, rIFNy was unable to induce Treg. CD4+CD25+ enriched PBL stimulated with PMA/lonomycin in the presence of rIFNy were rather resistant to the effect of rIFNy, in contrast to CD4+CD25- enriched PBL which showed increasing total Treg with Helios+ Treg switching from IFNY- to IFNY+ and increasing Helios-IFNy+ Treg. The data indicate that rIFNy, in combination with a polyclonal stimulus, activates nTreg and induces aTreg. When phorbol 12-myristate 13-acetate (PMA)/lonomycin was washed out from the cell culture after $6 \mathrm{~h}$ stimulation, Treg induction continued for at least $96 \mathrm{~h}$ of cell culture, contradicting the hypothesis that removal of the stimulus results in significant decrease of IFNy- and IFNy+CD4+CD25+Foxp3+CD127- Treg due to loss of Foxp3 expression.

Conclusions: IFNy+Helios- aTreg as well as IFNy+Helios+ nTreg are detectable in the blood of healthy individuals, show in part strong Foxp3 TSDR demethylation and are inducible in-vitro. The present data provide further insight concerning the in-vivo and in-vitro characteristics of IFNy+ Treg and help to understand their role in immunoregulation. Alloantigen-specific demethylated IFNy+Helios+ nTreg might represent a suitable marker for monitoring graft-specific immunosuppression in renal transplant recipients.

Keywords: IFNy+ nTreg, IFNy+ aTreg, Foxp3 TSDR demethylation, IFNy, Th1, Healthy individuals

\footnotetext{
* Correspondence: Volker.Daniel@med.uni-heidelberg.de

Department of Transplantation-Immunology, Institute of Immunology,

University Hospital Heidelberg, Im Neuenheimer Feld 305, 69120 Heidelberg, Germany
} link to the Creative Commons license, and indicate if changes were made. The Creative Commons Public Domain Dedication waiver (http://creativecommons.org/publicdomain/zero/1.0/) applies to the data made available in this article, unless otherwise stated. 


\section{Background}

$\mathrm{T}$ regulator cells (Treg) in the peripheral circulation of humans are usually IFN $\gamma-$. However, during stimulation CD4+CD25+CD127-Foxp3+ Treg are formed that coexpress IFN $\gamma$, as reviewed by Daniel et al. [1]. IFN $\gamma+$ Treg are detectable in the blood of renal transplant recipients with good long-term graft function and in patients with autoimmune disease, such as type-1 diabetes and multiple sclerosis [2-4]. They co-express IFN $\gamma$ receptors on the cell surface and are inducible by IFN $\gamma$ (auto- and paracrine activation) $[5,6]$. In addition to IFN $\gamma$, the cells produce TGFß and/or IL10 and co-express cell surface receptors that are involved in cell-cell contact inhibition as well as effector cell killing, such as CD152, CD178, CD95, and CD279 [6, 7]. Separated CD4+CD25+CD127-IFN + + Treg suppress MLCs unspecifically, although the strongest suppression is observed in antigen-specific mixed lymphocyte culture (MLC) settings $[5,7,8]$. The stronger the HLA incompatibility and proliferation in MLC experiments, the stronger the induction of CD4+CD25+Foxp3+IFN $\gamma+\mathrm{PBL}$ [8]. Interestingly, patients with poor long-term allograft function after renal transplantation are able to form CD4 +CD25+Foxp3+IFN $\gamma+$ PBL in MLC with pretransplant obtained peripheral blood lymphocytes (PBL) [8]. However, posttransplant these patients showed lower frequencies of these cells in the periphery than renal transplant recipients with good long-term graft outcome [2]. This finding suggests that patients with poor long-term graft outcome did not develop or lost this particular Treg subset posttransplant, perhaps because of intensified immunosuppressive treatment. The in-vitro behavior of IFN $\gamma+C D 4+C D 25+$ Foxp3+CD127- Treg suggests that they form the first line of Treg, patrolling in the body and searching for IFN $\gamma$ and initial immune responses that they subsequently suppress.

Origin and stability of suppressive function of IFN $\gamma+$ Treg are important factors with respect to the clinical relevance of this Treg subset [1]. Usually, the Foxp3 Tregspecific demethylated region (TSDR) of Tregs is demethylated, whereas that of conventional $\mathrm{T}$ cells is methylated $[9,10]$. TSDR methylation persists during transient expression of Foxp3 by convential T cells or unstable TGFßinduced Treg, whereas drug-induced demethylation of conventional $\mathrm{T}$ cells results in stable Foxp3 expression, suggesting that lineage stability in Treg may be epigenetically regulated. Signaling through IFN $\gamma R$ and IL12R, in combination with $\mathrm{T}$ cell receptor (TCR) engagement, induces strong expression of the transcription factor T-bet, which drives the differentiation of conventional $\mathrm{T}$ cells to a T helper type 1 (Th1) lineage [11]. The Ikaros family transcription factor Helios has been shown to be selectively expressed in nTreg of thymic origin but not in peripherally induced aTreg [12]. McClymont et al. reported that the majority of in-vitro induced IFN $\gamma+$ Tregs did not express Helios, suggesting that they were generated extrathymically [4]. Alternatively, they might belong to a minority of Helios- nTreg with demethylated TSDR expressing Foxp3, CD39, CTLA-4, CCL3 and IFN $\gamma$, as published by Himmel et al. [13]. Further experiments showed that nTreg can polarize towards IFN $\gamma+$ T cells in-vitro by IL12 conditioning whereby they remain Helios+, suggesting that part of the thymic-derived Treg population exhibits plasticity in cytokine production and expresses a Th1-like phenotype [4]. Hall et al. reported that rat nTreg stimulated with antigen and IFNY or IL12 expand and differentiate to antigen-specific IFN $\gamma+n$ Treg that have a 100- to 1000 -fold increased suppressor potency as compared to nTreg [14, 15]. This strongly potent antigen-specific nTreg subset with a Th1-like phenotype might represent a suitable marker for monitoring graft-specific immunosuppression in renal transplant recipients.

In the present study we examined the origin of IFN $\gamma+$ Treg as determined by Helios positivity in peripheral blood and PMA/Ionomycin-stimulated cell cultures performed with PBL from healthy individuals. Furtheron, we investigated whether IFN $\gamma+$ Treg can be induced by recombinant IFN $\gamma(\mathrm{rIFN} \gamma)$ without additional stimulus and whether IFN $\gamma+$ Treg after removal of the stimulus remain IFN $\gamma+$ Foxp3+ or, alternatively, decrease and differentiate to IFN $\gamma+$ Foxp3- Th1 and/or IFN $\gamma$-Foxp3+ Treg. Based on findings in mouse experiments, Feng et al. reported that in-vitro induced IFN $\gamma+$ Treg suppress inflammation effectively when transferred to mice with colitis but differentiate to Th1 lymphocytes when adoptively transferred to mice without inflammation [16]. Finally, we determined the Foxp3 TSDR demethylation status of separated IFN $\gamma+$ Treg in order to assess stability of Foxp3 expression.

\section{Results}

\section{Treg subsets in peripheral blood of healthy controls}

Figure 1 demonstrates the gating strategy. Figure 2 depicts Treg subset numbers in the blood of 12 healthy individuals. Mean \pm SEM (range) of circulating CD4 $+\mathrm{PBL}$ was $799 \pm 220 / \mu \mathrm{l}(483-1179 / \mu \mathrm{l})$ and of circulating CD4+CD25+Foxp3+CD127- Treg $3.0 \pm 1.4 / \mu \mathrm{l}(1.2-6.4 / \mu \mathrm{l})$. Approximately two-thirds of all Treg expressed the classical nTreg phenotype Helios+IFN $\gamma^{-}(1.9 \pm 1.1 / \mu \mathrm{l}$; $0.7-3.7 / \mu \mathrm{l})$. In contrast, only a small minority of Treg produced IFN $\gamma$ and was Helios+IFN $\gamma+(0.1 \pm 0.1 / \mu \mathrm{l} ; 0-$ $0.4 / \mu \mathrm{l})$ or Helios-IFN $\gamma+(0.1 \pm 0.1 / \mu \mathrm{l} ; 0-0.5 / \mu \mathrm{l})$. Half of IFN $\gamma+$ Treg appear to originate from the thymus (Helios+) and represent activated nTreg, whereas the other half appear to be induced in the periphery (Helios-) and represent aTreg. CD4+CD25+Foxp3+CD127- Treg were found to express TGFß, CD62L, CXCR3, CD152, Perforin, Granzyme B, CD28, HLA-DR, CD95, CD178, CD154, Tbet and IFN $\gamma$ R1 CD119. The data suggest that IFN $\gamma+$ 


\section{a}
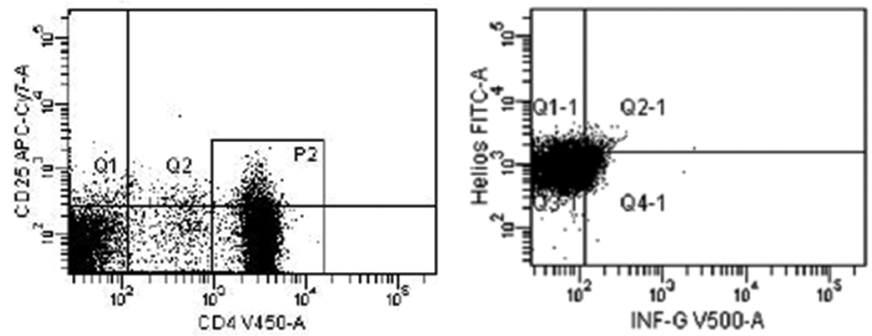

b
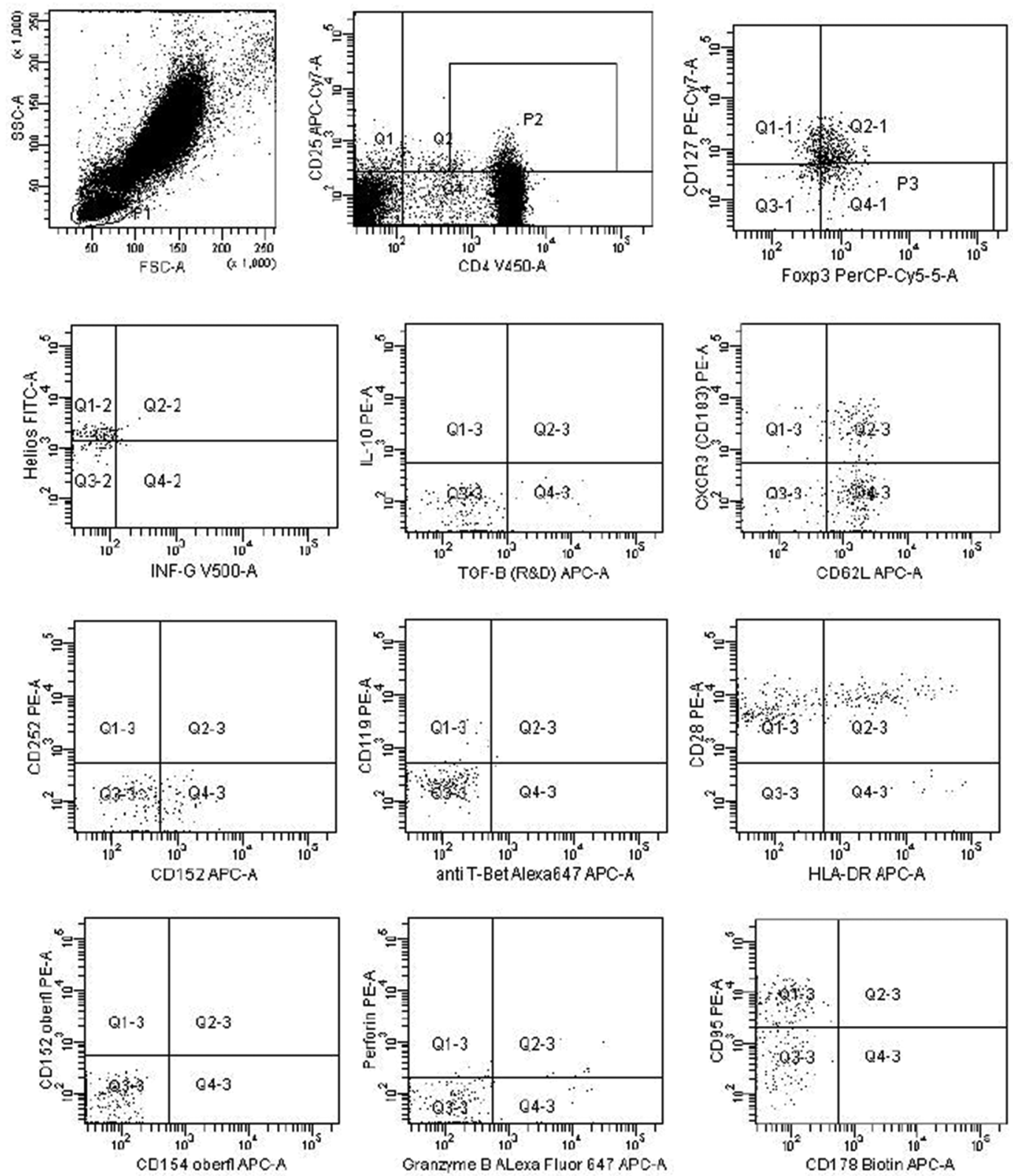

Fig. 1 (See legend on next page.) 
(See figure on previous page.)

Fig. 1 Determination of Treg subsets. a Total CD4+ lymphocytes of a healthy individual were gated (gate P2) and further analysed concerning intracellular Helios and IFNy positivity. The majority of circulating CD4+ lymphocytes was Helios- and this gate was used for all further flow cytometric analyses of Helios positivity. $\mathbf{b}$ Stepwise gating strategy for Treg subset determination: first, lymphocytes gate (P1), then CD4+CD25+ PBL gate (P2), Foxp3+CD127- gate (P3), and finally Helios/IFNy gate. Further CD4+CD25+Foxp3+CD127- Treg subsets (based on gate P3) were analysed using the depicted gate settings for IL10/TGFß, CXCR3/CD62L, CD252/CD152 (CD152 intracellular), CD119/Tbet, CD28/HLA-DR, CD152/CD154 (both surface), Perforin/GranzymeB, and CD95/CD178

Treg have the potential to enter secondary lymphoid organs as well as inflamed tissues (CD62L, CXCR3) and are able to induce suppression of immune responses either by apoptosis (CD95, CD178), cell death (Perforin, Granzyme B), cytokine secretion (TGFß) or cell-cell interaction (CD152, CD154). Moreover, they have the potency to regulate production as well as consumption of IFN $\gamma$ in the cell by surface receptors (CD119) and induction of transcription factors (Tbet). Interestingly, IL10+ Treg phenotypes were undetectable in the circulation whereas TGFß+ IFN $\gamma+$ Treg were rather frequent (Fig. 2).

\section{Cell cultures stimulated with rIFN $\gamma$ only}

As shown previously, IFN $\gamma+$ Treg express IFN $\gamma$ receptors [6]. We hypothesized that IFN $\gamma+$ Treg might be inducible by recombinant rIFNY without additional stimulus. When unseparated PBL of 4 healthy volunteers were stimulated with 500 or $1000 \mathrm{ng} / \mathrm{ml} \mathrm{rIFN \gamma}$ for 24 and $48 \mathrm{~h}$, there was no statistically significant increase in any of the Treg subsets depicted in Fig. 3 ( $24 \mathrm{~h}$ resp. $48 \mathrm{~h}: 0 \mathrm{ng} / \mathrm{ml}$ vs $500 \mathrm{ng} / \mathrm{ml}$ resp. $1000 \mathrm{ng} / \mathrm{ml} \mathrm{rIFN} \gamma, p=$ n.s.). Rather, there was a decrease of CXCR3+CD62L+ $(48 \mathrm{~h}: 0 \mathrm{ng} / \mathrm{ml} \mathrm{vs}$ $500 \mathrm{ng} / \mathrm{ml}$ resp. $1000 \mathrm{ng} / \mathrm{ml} \mathrm{rIFN \gamma}$, both $p=0.029$ ) as well as CD152+CD154+ (48 h: $0 \mathrm{ng} / \mathrm{ml}$ vs $1000 \mathrm{ng} / \mathrm{ml} \mathrm{rIFN \gamma}$, $p=0.029)$ Treg. The data suggest that rIFN $\gamma$ is unable to induce Treg, especially IFN $\gamma+$ Treg, in the absence of an additional stimulus.

\section{IFN $\gamma+$ Treg induced in-vitro in the presence of both rIFN $\gamma$} and PMA/lonomycin

We speculated that rIFN $\gamma$ might induce IFN $\gamma+$ Treg only in combination with an additional stimulus, such as PMA/Ionomycin, and that activated nTreg with Helios+IFN $\gamma+$ phenotype originate mainly from the $\mathrm{CD} 4+\mathrm{CD} 25+\mathrm{PBL}$ preparation. We therefore investigated the induction of IFN $\gamma+$ Treg in cell cultures with unseparated PBL, enriched CD4+CD25+ and enriched CD4+CD25- PBL preparations. CD4+ PBL were enriched to $99 \pm 0.6 \%$ purity. $\mathrm{CD} 4+\mathrm{CD} 25+$ enriched PBL fractions contained $87 \pm 9.9 \%$ and the remaining CD4+CD25- PBL preparation $33 \pm 10.6 \%$ CD4+CD25+ PBL. PBL preparations of 5 healthy individuals were stimulated for $72 \mathrm{~h}$ with PMA/Ionomycin in the presence of $500 \mathrm{ng} / \mathrm{ml}$, $1000 \mathrm{ng} / \mathrm{ml}, 5000 \mathrm{ng} / \mathrm{ml}$ or without $\mathrm{rIFN} \gamma$.

\section{Unseparated PBL}

Stimulation of unseparated PBL with PMA/Ionomycin alone for $24 \mathrm{~h}$ increased the proportions of total CD4 +CD25+Foxp3+CD127- (24 h: with vs without PMA/ Iono: $p=0.056)$ and Helios-IFN $\gamma+(p=0.008)$ Treg, but decreased the proportion of Helios+IFN $\gamma$-IL10TGFß $+(p=0.056)$ Treg (Fig. 4a). Addition of rIFN $\gamma$ to PMA/Ionomycin-stimulated cell cultures decreased the proportions of Helios+IFN $\gamma-(24 \mathrm{~h}$ resp. $48 \mathrm{~h}$ : PMA/ Iono vs PMA/Iono $+5000 \mathrm{ng} / \mathrm{ml} \mathrm{rIFN} \gamma, p=0.016 \mathrm{resp}$. $p=0.008)$ and Helios+IFN $\gamma-$ IL10-TGF $\beta+(48 \mathrm{~h}:$ PMA/

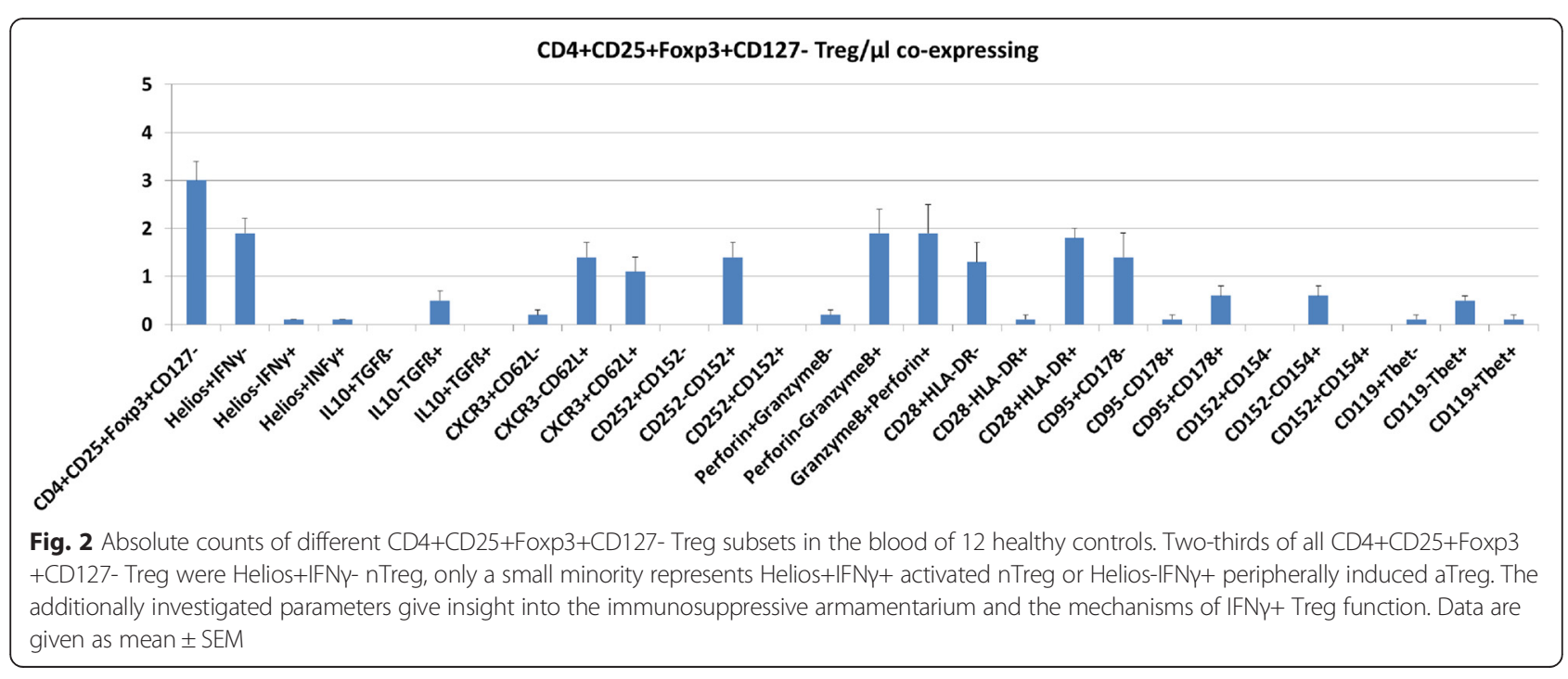




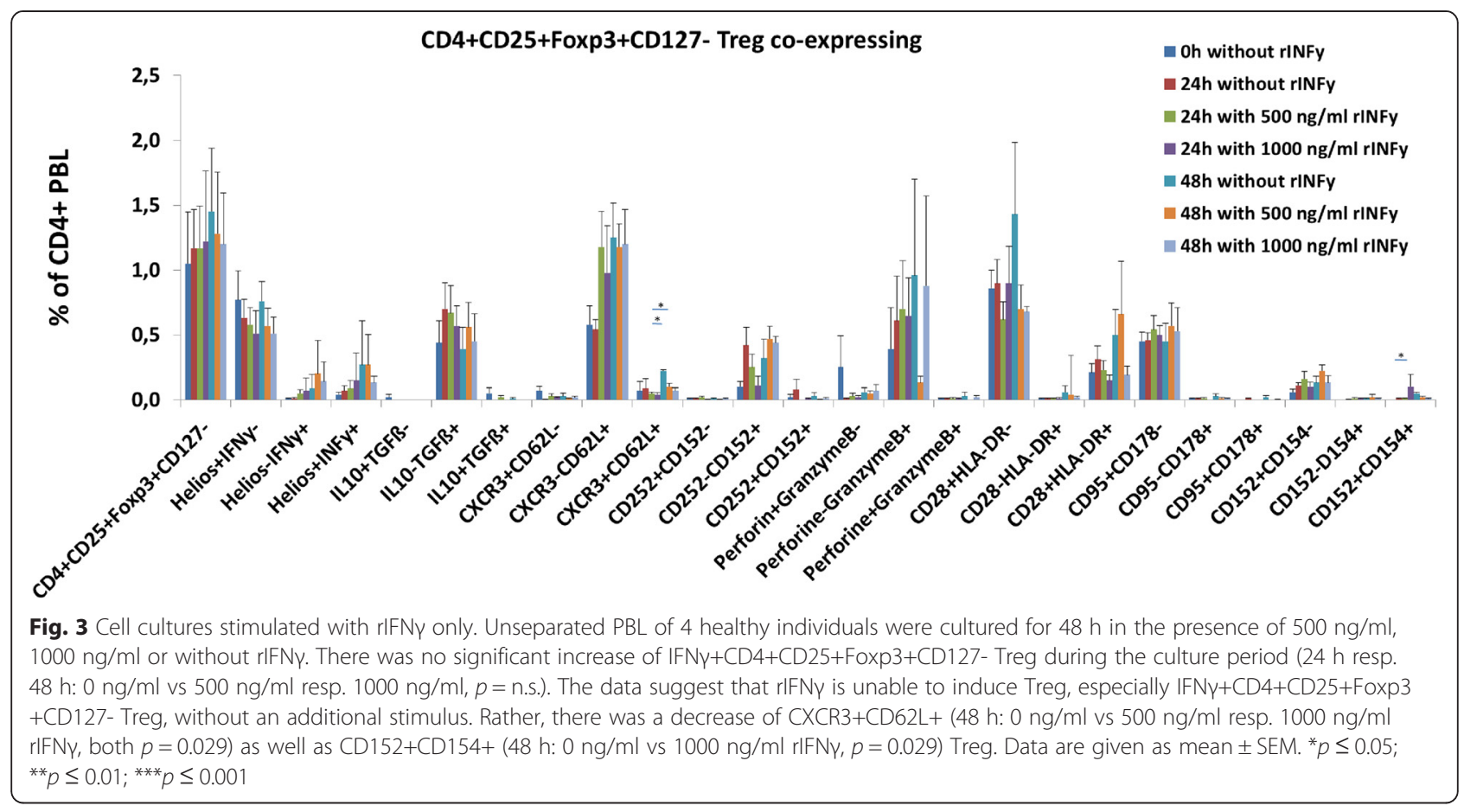

Iono vs PMA/Iono + 500 resp. 1000 resp. $5000 \mathrm{ng} / \mathrm{ml}$ rIFN $\gamma, p=0.016$ resp. $p=0.008$ resp. $p=0.008)$ Treg and increased the proportion of Helios-IFN $\gamma+(24 \mathrm{~h}$ : PMA/ Iono vs PMA/Iono $+5000 \mathrm{ng} / \mathrm{ml} \mathrm{rIFN} \gamma, p=0.032)$ Treg. It appears that rIFN $\gamma$ decreased the Helios+IFN $\gamma$ - and increased the Helios-IFN $\gamma+$ Treg subset in PMA/Ionomycinstimulated cell cultures.

\section{Enriched $C D 4+C D 25+P B L$}

When, instead of unseparated PBL, cell preparations enriched for $\mathrm{CD} 4+\mathrm{CD} 25+\mathrm{PBL}$ were stimulated, addition of rIFNy increased Helios-IFN $\gamma+$ (24 h: PMA/Iono vs PMA/Iono + $500 \mathrm{ng} / \mathrm{ml}$ rIFN $\gamma, p=0.056)$ Treg. Helios $+\mathrm{IFN} \gamma+$ Treg decreased (48 h: PMA/Iono vs PMA/Iono + $500 \mathrm{ng} / \mathrm{ml} \mathrm{rIFN \gamma} ; p=0.056$ ) but tended to increase in the presence of higher rIFN $\gamma$ concentrations in the culture medium ( $p=$ n.s.) (Fig. 4b).

\section{Enriched CD4+CD25- PBL}

Stimulation of enriched CD4+CD25- PBL with PMA/Ionomycin alone increased total CD4+CD25+Foxp3+CD127( $24 \mathrm{~h}$ : with vs without PMA/Iono: $p=0.016$ ) and Helios $+\mathrm{IFN} \gamma-(p=0.056)$ as well as Helios+IFN $\gamma+(p=0.056)$ Treg (Fig. 4c). When rIFN $\gamma$ was added to PMA/Ionomycin-stimulated cell cultures, a decrease of Helios+IFNyTreg was noted (24 h: PMA/Iono vs PMA/Iono +1000 resp. $5000 \mathrm{ng} / \mathrm{ml}$ rIFN $\gamma, p=0.056$ resp. $p=0.008 ; 48 \mathrm{~h}$ : PMA/Iono vs PMA/Iono +1000 resp. $5000 \mathrm{ng} / \mathrm{ml} \mathrm{rIFN \gamma}$, $p=0.032$ resp. $p=0.008$ ) as well as of Helios+IFN $\gamma$-IL10TGFß+ (48 h: PMA/Iono vs PMA/Iono + 1000 resp. $5000 \mathrm{ng} / \mathrm{ml} \mathrm{rIFN} \gamma, p=0.008$ resp. $p=0.008)$, whereas
Helios-IFN $\gamma+(48 \mathrm{~h}$ : PMA/Iono vs PMA/Iono + 1000 resp. $5000 \mathrm{ng} / \mathrm{ml} \mathrm{rIFN} \gamma, p=0.032$ resp. $p=0.032)$ Treg increased. A strong increase of total CD4+CD25+Foxp3 $+\mathrm{CD} 127-(p=0.008)$ and Helios+IFN $\gamma+(p=0.016)$ Treg as well as an increase of Helios-IFN $\gamma+(p=0.056)$ Treg was observed when freshly separated CD4+CD25- PBL were compared with CD4+CD25- PBL after 24 h stimulation with PMA/Ionomycin.

The data suggest that rIFN $\gamma$ in combination with PMA/ Ionomycin decreases Helios+IFN $\gamma$ - and increases HeliosIFN $\gamma+$ Treg in-vitro and that this effect was more pronounced in cell cultures with enriched CD4+CD25- than in cell cultures with CD4+CD25+ PBL. Treatment with rIFN $\gamma$ appears to increase total Treg that are HeliosIFN $\gamma+$ and induces a switch of Helios+ Treg from IFN $\gamma-$ to IFN $\gamma+$. We conclude that rIFN $\gamma$ in combination with a polyclonal stimulus induces aTreg and activates nTreg.

Kinetics of Treg subsets in-vitro in culture of CD4+CD25+ or CD4+CD25- PBL preparations after elimination of the stimulus

Next, we studied the fate of Treg subsets after removal of a short-term polyclonal stimulus. CD4+CD25+ enriched (82 $\pm 15 \%$ CD4+CD25+ PBL) and CD4+CD25+ depleted (33 $\pm 5.3 \% \mathrm{CD} 4+\mathrm{CD} 25+\mathrm{PBL})$ cell preparations as well as unseparated PBL from 3 healthy individuals were stimulated with PMA/Ionomycin for 6 h. PMA/Ionomycin was washed out of the cell culture and Treg subsets were analyzed again at 7, 24, 72 and $96 \mathrm{~h}$. In PBL cell cultures, total CD4+CD25+Foxp3+CD127- (7 h vs $72 \mathrm{~h}, p=0.029)$ and Helios+IFN $\gamma+(7 \mathrm{~h}$ vs $72 \mathrm{~h}, p=0.045)$ Treg increased after 


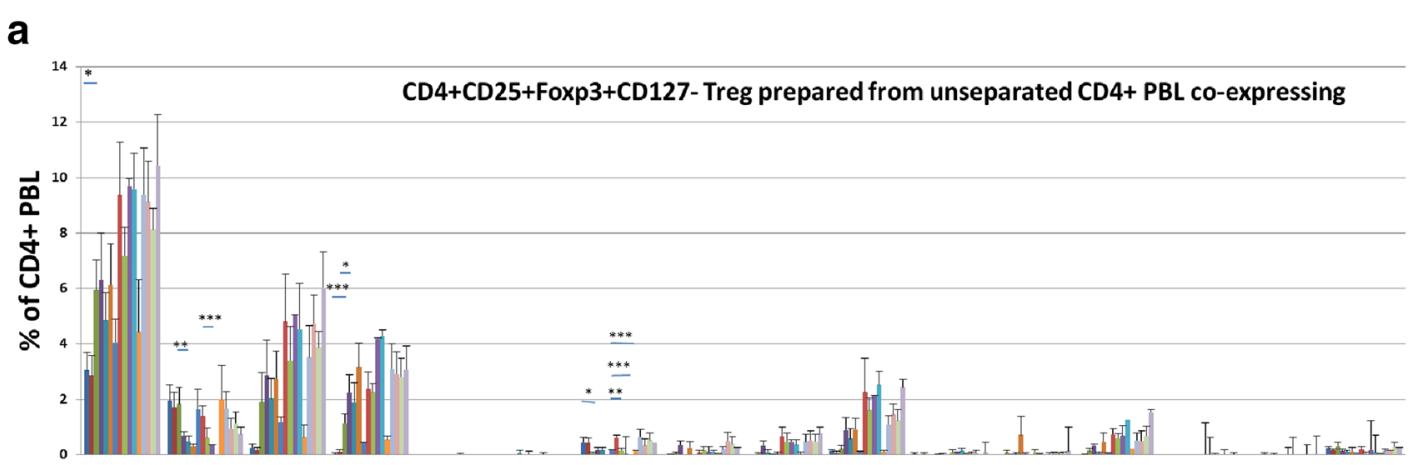

b

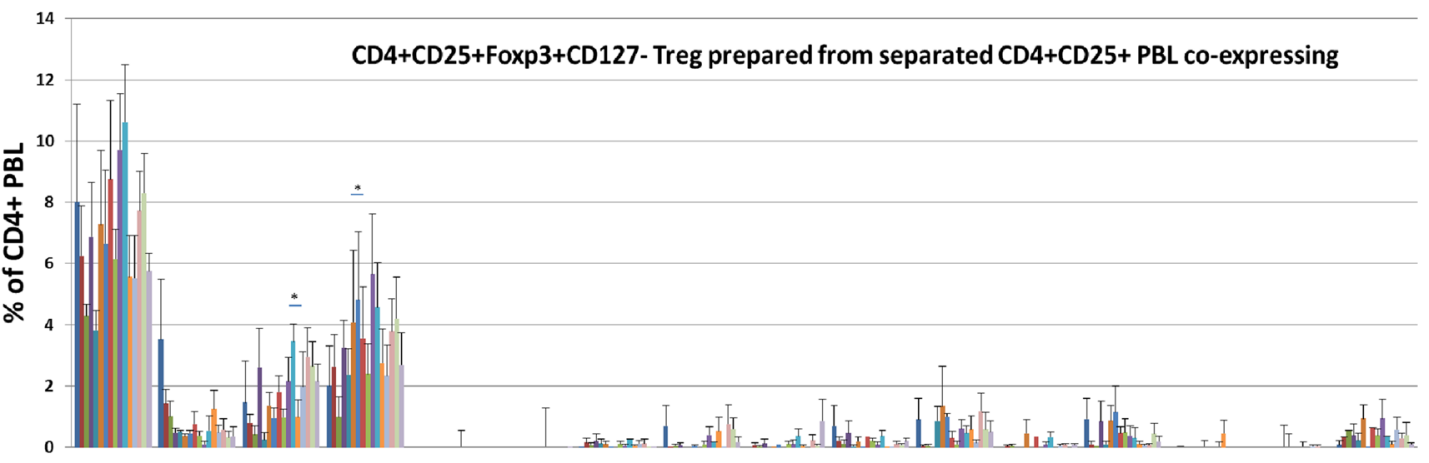

C
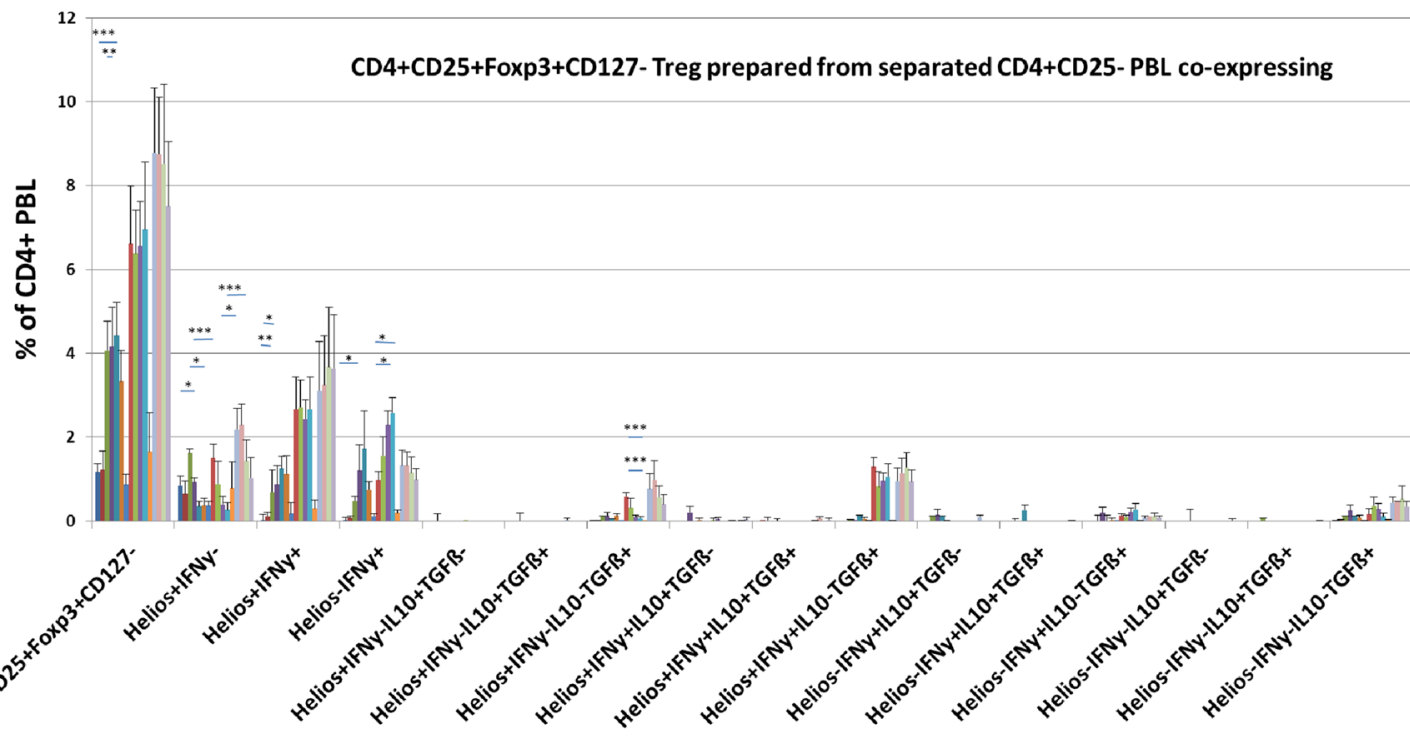

口 0 h; $\varnothing$ PMA/lono; 0 ng/ml rIFNy

$\square 24$ h; PMA/Iono; 500 ng/ml rIFNy

$\square 8$ h; $\emptyset$ PMA/Iono; 0 ng/ml rIFNy

48 h; PMA/Iono; 5000 ng/ml rIFNy

72 h; PMA/Iono; 500 ng/ml rIFNy
口 24 h; $\emptyset$ PMA/Iono; 0 ng/ml rIFNy

— 24 h; PMA/Iono; 1000 ng/ml rIFNy

$48 \mathrm{~h}$; PMA/Iono; $0 \mathrm{ng} / \mathrm{ml}$ rIFNy

- 72 h; $\varnothing$ PMA/Iono; 0 ng/ml rIFNy

72 h; PMA/Iono; 1000 ng/ml rIFNy
24 h; PMA/Iono; 0 ng/ml rIFNy 24 h; PMA/Iono; 5000 ng/ml rIFNy 48 h; PMA/Iono; 500 ng/ml rIFNy 72 h; PMA/Iono; 0 ng/ml rIFNy 72 h; PMA/Iono; 5000 ng/ml rIFNy

Fig. 4 (See legend on next page.) 
(See figure on previous page.)

Fig. 4 IFNY + Treg induced in-vitro in the presence of both rIFNy and PMA/lonomycin. a PBL of 5 healthy individuals were stimulated for $72 \mathrm{~h}$ using PMA/lonomycin in the presence of 500, 1000, $5000 \mathrm{ng} / \mathrm{ml}$ or without rIFNy. PMA/lonomycin-stimulated cultures without rlFNy were compared with those stimulated in the presence of rIFNy. b, c The same assay was performed using cell cultures with enriched CD4+CD25+ or enriched CD4+CD25- PBL. The data suggest that CD4+CD25+ PBL are rather resistant to the effect of rlFNy. In contrast, CD4+CD25- enriched PBL showed increasing total Treg with both Helios+ Treg switching from IFNY- to IFNy+ and increasing IFNy+Helios- Treg indicating that rIFNy in combination with a polyclonal stimulus induces activation of nTreg as well as induction of aTreg. Data are given as mean \pm SEM. ${ }^{*} p \leq$ $0.05 ;{ }^{* *} p \leq 0.01 ;{ }^{* * *} p \leq 0.001$

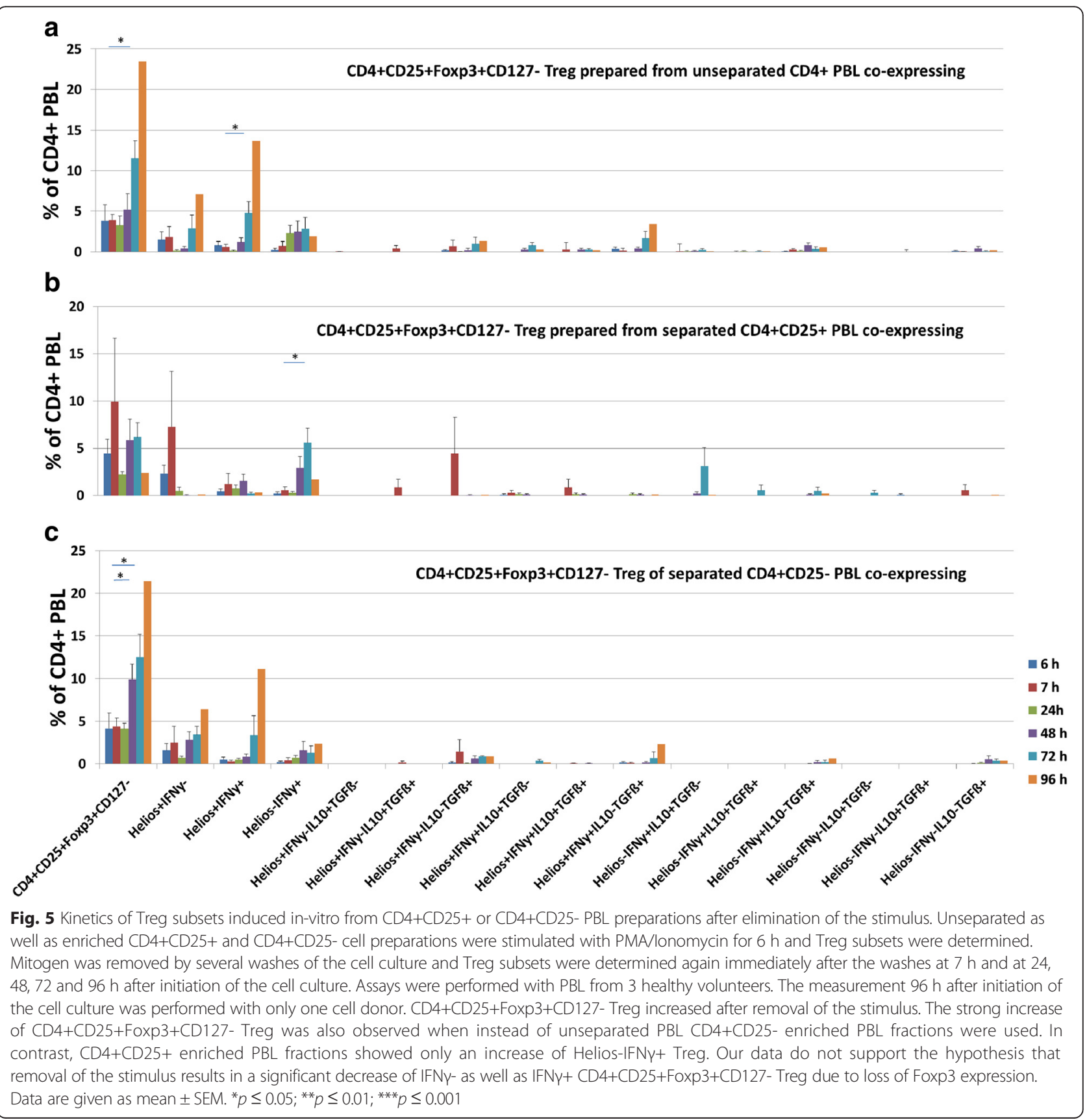




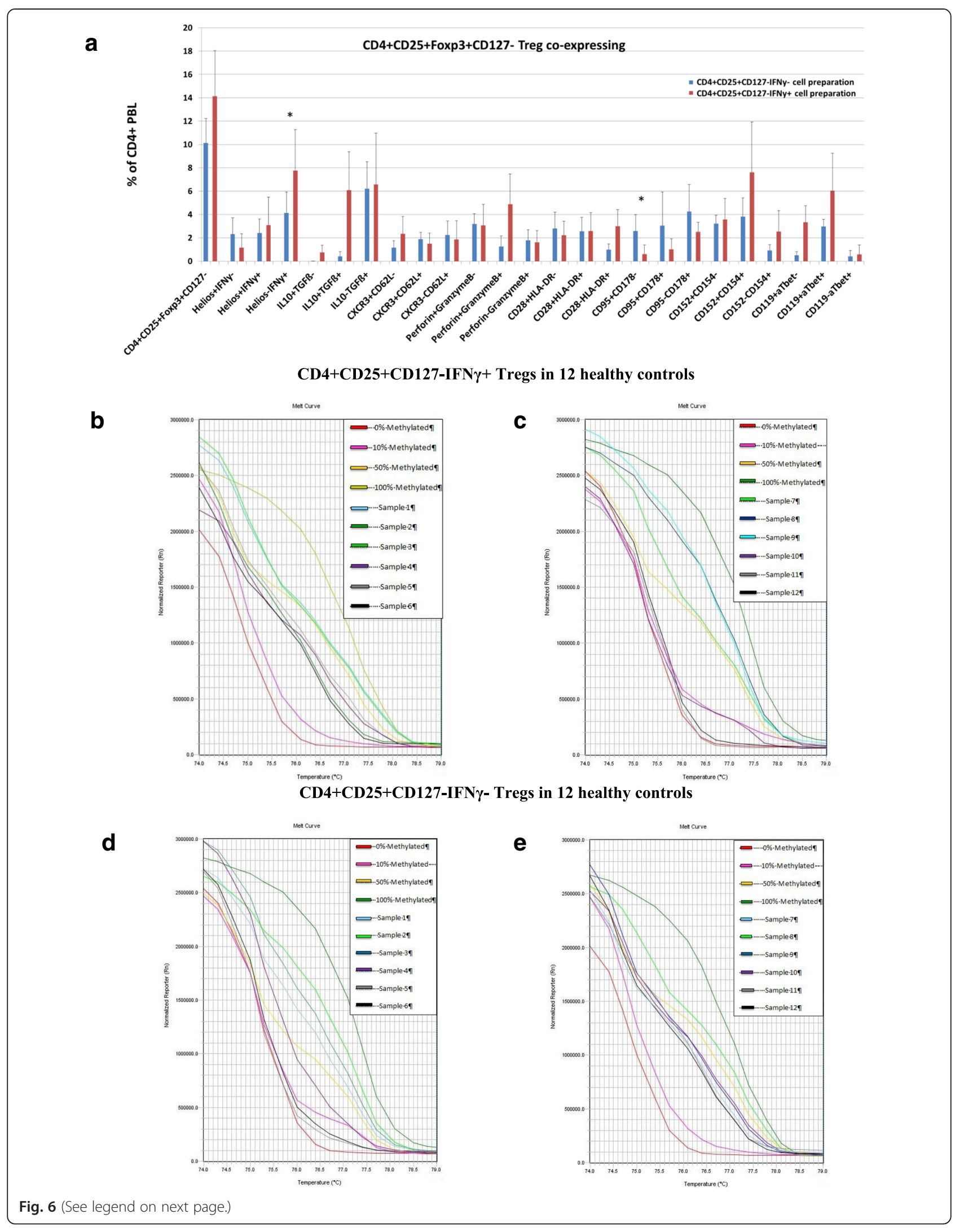


(See figure on previous page.)

Fig. 6 Treg subsets and Foxp3 TSDR DNA methylation analysis in enriched CD4+CD25+CD127-IFNy+PBL preparations. a CD4+CD25+CD127-IFNy+ Treg were separated from CD4+CD25+CD127-IFNy- Treg using PBL from 5 different healthy volunteers. CD4+CD25+Foxp3+CD127- co-expressing Helios-IFNy+ were significantly enriched in the IFNy+ Treg preparation whereas CD95+CD178- Treg were depleted compared to IFNy- Treg preparations. Data are given as mean \pm SEM. ${ }^{*} p \leq 0.05$. b-d Foxp3 TSDR DNA methylation analysis of enriched CD4+CD25+CD127-IFNY+ (b, c) and enriched CD4+CD25 + CD127-IFNY- (d, e) Treg fractions from 12 healthy individuals (samples $1-12$ ). Figure $\mathbf{b}$ and $\mathbf{d}$ and Fig. $\mathbf{c}$ and e correspond with each other showing test results of the same individuals. In addition, melt curves of the standards with 0, 10, 50 and $100 \%$ methylated Foxp3 TSDR DNA are depicted in each diagram. 4 of 6 IFNy+ Treg preparations in Fig. 6b, 3 of 6 IFNy+ Treg preparations in (c), 3 of 6 IFNy- Treg preparations in (d) and 5 of 6 IFNy- Treg preparations in (e) showed a Foxp3 TSDR methylation of $<50 \%$ representing mainly demethylated Treg with stable Foxp3 expression

removal of the stimulus (Fig. 5a). An increase of CD4 +CD25+Foxp3+CD127- (7 h vs $48 \mathrm{~h}$ resp. $72 \mathrm{~h}, p=0.053$ resp. $p=0.047$ ) was also observed when $\mathrm{CD} 4+\mathrm{CD} 25$ enriched PBL fractions were studied instead of unseparated PBL (Fig. 5c). In contrast, CD4+CD25+ enriched PBL fractions showed only an increase of Helios-IFN $\gamma+$ Treg (7 h vs $72 \mathrm{~h}, p=0.034$ ) (Fig. 5b). Our data do not support the hypothesis [17-24] that removal of the stimulus results in a significant decrease of IFN $\gamma$ - as well as IFN $\gamma+$ CD4+CD25 +Foxp3+CD127- Treg due to loss of Foxp3 expression. We found that Helios+ as well as Helios- IFN $\gamma+$ Treg increased during the $96 \mathrm{~h}$ observation period.

\section{Foxp3 TSDR DNA methylation status of IFN $\gamma+$ and IFNY- Treg preparations}

Because IFN $\gamma+\mathrm{CD} 4+\mathrm{CD} 25+$ Foxp3+CD127- Treg are nearly undetectable in the blood of healthy controls, IFN $\gamma+$ Treg were purified by sequential enrichment of $\mathrm{CD} 4+$, CD25+, CD127- and IFN $\gamma+$ PBL resulting in CD4+CD25 $+\mathrm{CD} 127-\mathrm{IFN} \gamma+$ and CD4+CD25+CD127-IFN $\gamma-$ Treg preparations (Fig. 6a). Cell preparations $(n=5)$ enriched of IFN $\gamma+$ PBL had higher Helios-IFN $\gamma+(p=0.043)$ Treg. Foxp3 TSDR DNA methylation was analyzed in enriched CD4+CD25+CD127-IFN $\gamma+$ and CD4+CD25 $+\mathrm{CD} 127-\mathrm{IFN} \gamma$ - Treg preparations from 12 healthy individuals. Figure $6 \mathrm{~b}+\mathrm{c}$ shows the melt curves obtained with CD4+CD25+CD127-IFN $\gamma+$ Treg fractions, Fig. $6 \mathrm{~d}+\mathrm{e}$ the melt curves obtained with CD4+CD25+CD127-IFN $\gamma-$ Treg preparations. 7 of the $12 \mathrm{CD} 4+\mathrm{CD} 25+\mathrm{CD} 127-\mathrm{IFN} \gamma+$ and 8 of the 12 CD4+CD25+CD127-IFN $\gamma$ - Treg preparations showed partial Foxp3 TSDR methylation of $<50 \%$ and 3 of the CD4+CD25+CD127-IFN $\gamma+$ and 2 of the CD4 + CD25+CD127-IFN $\gamma$ - Treg preparations exhibited a very low Foxp3 TSDR methylation of $<10 \%$, suggesting that IFN $\gamma+$ and IFN $\gamma$ - Treg preparations show similar patterns of demethylated Foxp3 TSDR. It appears that part of IFN $\gamma+$ Treg have stable Foxp3 expression and might represent activated $n$ Treg.

\section{Discussion}

We studied frequencies of IFN $\gamma+$ Treg subsets in the peripheral blood of healthy individuals and investigated whether IFN $\gamma+$ Treg originate from Helios+ CD4+CD25+ thymus-derived nTreg and might represent activated
nTreg with Foxp3 TSDR demethylation, stable Foxp3 expression and strong suppressive potency, or, alternatively, differentiate peripherally from Helios- CD4+CD25conventional $\mathrm{T}$ lymphocytes representing aTreg with Foxp3 TSDR methylation, transient expression of Foxp3 and low suppressive capacity [1].

Our data indicate that healthy individuals have both types of IFN $\gamma+$ Treg in the blood and that both cell types co-express determinants characteristic for Treg. However, only very few IFN $\gamma+$ Treg in the blood can be separated with respect to Helios positivity into activated nTreg and aTreg. Few of IFN $\gamma+$ as well as IFN $\gamma$ - Treg preparations showed strong demethylation of Foxp3 TSDR, supporting the hypothesis that part of IFN $\gamma+$ Treg represent activated nTreg. As shown by Hall et al. in rats, activated nTreg form after stimulation with alloantigen in the presence of IFNy or IL12 and express a Th1-like phenotype $[14,15]$. They have a 100 - to 1000-fold increased suppressor potency over nTreg that were generated by antigen unspecific stimulation with IL2 alone. These alloantigen-specific IFN $\gamma+n$ Treg, formed and activated in the presence of IFN $\gamma$, might be suitable candidates for Treg monitoring in organ-grafted patients. An increase of this particular Treg subset might indicate suppression of the graft-specific immune response. In a previous study, we were able to show that renal transplant recipients with good long-term graft function possessed higher proportions of IFN $\gamma+$ Treg than patients with impaired long-term graft function [2]. Helios positivity and Foxp3 TSDR methylation status of IFN $\gamma+$ Treg were not determined in that study.

Our current in-vitro data show that IFNY alone is unable to induce this Th1-like Treg subset. However, IFNy in combination with a second stimulus amplifies the activation of nTreg switching from IFN $\gamma$ - to IFN $\gamma+$, and, in addition, induces the differentiation of IFN $\gamma+$ aTreg. This observation supports our hypothesis that IFN $\gamma+$ Treg represent the first line of Treg during an immune response. However, what is the fate of IFN $\gamma+$ Treg when the immune response is stopped? Do they become apoptotic or do they further differentiate to Th1 lymphocytes, losing their Foxp3 expression and forming potentially harmful graft-specific Th1 lymphocytes? Our data show that during $90 \mathrm{~h}$ after elimination of the polyclonal 
stimulus from the cell culture, both IFN $\gamma+$ nTreg and IFN $\gamma+$ aTreg continue to increase. Feng et al. reported that in-vitro induced murine IFN $\gamma+$ Treg suppress inflammation effectively when transferred to mice with colitis, but differentiate to Th1 lymphocytes when adoptively transferred to mice without inflammation [16]. IFN $\gamma+$ Treg that were exposed to an IFN $\gamma$-containing milieu during our in-vitro experiments or after transfer into inflamed tissues during the in-vivo experiments of Feng et al. [16] remained phenotypically and functionally stable. Based on the experiments of Feng et al. [16], we speculate that IFN $\gamma+$ Treg, when not stimulated further by IFN $\gamma$, remain as resting harmless nTreg or Foxp3-IFN $\gamma$ - Th1 lymphocytes that do not attack the graft in a transplant recipient. We believe that in stable transplant recipients the lack of IL12 and IFN $\gamma$ in the in-vivo milieu might render these per se graft-specific cells, which differentiated from Th1like Treg to Th1 lymphocytes, harmless.

As shown in the blood of healthy individuals, Helios + IFN $\gamma+$ Treg co-express TGFß but not IL10. Further analysis of Treg phenotypes showed that Treg coexpressed, in-addition, Granzyme B and Perforin as well as Fas (CD95) and FasL (CD178), thereby affording the Treg the capacity to induce lysis and apoptosis of target cells [6]. Moreover, expression of CTLA-4 (CD152) and CD40L (CD154) imply cell-cell contact-dependent immunosuppression by these Treg subsets. CXCR3 and CD62L expression suggests that part of these cells have the potential to enter secondary lymphoid organs as well as inflamed tissues $[25,26]$. These Treg exhibit Th1 characteristic properties such as IFNyR1 (CD119) and Tbet expression, which means they have the potency to regulate expression as well as consumption of IFNY in the cell. CD28 is involved in Treg activation and HLA-DR expression indicates activation of Treg [27]. Our present experiments show that these cell markers are expressed on IFN $\gamma+$ as well as IFN $\gamma$ - Treg in the peripheral blood (frequency of each subset: $<10 \%$ of CD4+CD25+Foxp3 +CD127- Treg; data not shown) and this observation confirms the results of our previously published in-vitro studies $[6,7]$. Expression of TGF, CD183, CD62L, CD152, CD28, CD178, CD95, CD119, T-bet, HLA-DR, Perforin and Granzyme B in/on circulating CD4+CD25+Foxp3 $+\mathrm{CD} 127$ - Treg provides insight into the immunosuppressive armamentarium and the mechanisms of IFN $\gamma+$ Treg function. Selection of the most appropriate Treg population for cell therapy is a critical step in ensuring successful clinical outcomes, as reviewed recently [28].

\section{Conclusions}

In the blood of healthy individuals, two-thirds of all CD4 +CD25+Foxp3+CD127- Treg were found to be Helios $+\mathrm{IFN} \gamma$ - nTreg. Only a small minority represents Helios $+\mathrm{IFN} \gamma+$ activated nTreg or Helios-IFN $\gamma+$ peripherally induced aTreg. Both IFN $\gamma+$ and IFN $\gamma$ - Treg preparations contain in part strongly demethylated Foxp3 TSDRs, indicating stable Foxp3 expression characteristic for nTreg. During polyclonal stimulation in the presence of rIFN $\gamma$, Helios-IFN $\gamma+$ aTreg are induced and resting Helios+IFN $\gamma-$ nTreg differentiate to activated Helios+IFN $\gamma+$ thymically-derived nTreg. rIFN $\gamma$ alone is unable to induce this differentiation. Polyclonal activation induces the expression of IFN $\gamma \mathrm{R} 1$ (CD119) and these receptors are necessary for the stimulating effect of autoand paracrine secreted IFN $\gamma$. CD119 is expressed on IFN $\gamma^{+}$, IFN $\gamma^{-}$, Helios+ as well as Helios- Treg. The frequency of each subset in the peripheral blood was $<5 \%$ of CD4+CD25+Foxp3+CD127- Treg (data not shown). The present data provide further insight into the in-vivo and in-vitro characteristics of IFN $\gamma+$ Treg and help to understand their role in immunoregulation. Alloantigen-specific demethylated IFN $\gamma+$ Helios+ nTreg might represent a suitable marker for monitoring graft-specific immunosuppression in renal transplant recipients.

\section{Methods \\ Healthy controls}

Laboratory staff served as healthy controls. All controls gave informed consent for the tests performed within this study. The study was reviewed by the ethics committee of the University of Heidelberg and was performed in accordance with the ethical standards laid down in the 2000 Declaration of Helsinki as well as the Declaration of Istanbul 2008. All healthy individuals gave their informed consent prior to their inclusion in the study.

\section{Stimulation of PBL using PMA/lonomycin}

PBL were separated from heparinized or EDTA whole blood by Ficoll densitiy gradient centrifugation and stimulated for different time intervals using a mixture of phorbol 12-myristate 13-acetate (PMA; final concentration in medium: 10 ng/ml; Sigma Aldrich, Munich, Germany) and ionomycin ( $1 \mu \mathrm{g} / \mathrm{ml}$; Sigma Aldrich, Munich, Germany) in RPMI medium containing $10 \%$ FCS, L-Glutamin, and Penicillin/ Streptomycin (all from Invitrogen Gibco, Paisley, Scotland) as described previously [5].

\section{Determination of different PBL subsets}

PBL subsets were determined as described previously [2, 5]. For analysis of determinants on the cell surface, PBL were incubated with fluorochrome-labelled monoclonal antibodies against CD3, CD4, CD25, CD28, CD62L, CD95, CD119, CD127, CD152, CD154, CD178, CD252, HLA-DR, and CD183 (CXCR3) (all from BD Biosciences). Intracellular determinants were stained with fluorochrome-labelled monoclonal antibodies against Foxp3, IFNY (clone B27), IL4, IL10, Granzyme B, Perforin, T-bet (all from BD Biosciences), Helios (ebioscience, Frankfurt, Germany) 
and TGF $\beta_{1}$ (R\&D systems, Wiesbaden). Briefly, PBL were incubated with combinations of monoclonal antibodies for $30 \mathrm{~min}$ as described and eight-color fluorescence was analyzed using a FACSCanto II triple-laser flow cytometer (BD Biosciences) [2, 5]. When, in addition, intracellular proteins were studied, cell membranes were permeabilized using BD Perm/Wash buffer (BD Biosciences). At least 100,000 events were analyzed in the initial FSC/SSC dot plot. IFNY monoclonal antibody used for cell separation (BD clone 4S.B3) and IFN $\gamma$ monoclonal antibody used for cell staining (BD clone B27) were not competitive (data not shown).

\section{Enrichment of CD4+CD25+CD127-IFN $\gamma+$ Treg}

Using this procedure, CD4+CD25+CD127-IFN $\gamma+$ Treg were enriched by $>80 \%$. CD4 $4^{+}$and CD25+ PBL were subsequently separated by positive selection using StrepTactin magnetic Microbeads (IBA, Göttingen, Germany) according to the instructions of the manufacturer. Briefly, $4 \mu \mathrm{l}$ Fab-Strep were mixed with $1 \mu \mathrm{l}$ Buffer IS. Then, $15 \mu \mathrm{l}$ from the homogeneously resuspended Strep-Tactin Magnetic Microbeads were added to the Fab-Strep solution and incubated overnight at $4{ }^{\circ} \mathrm{C}$. The pre-incubated FabStrep Microbead preparation was added to the cells and mixed gently for $20 \mathrm{~min}$ at $4{ }^{\circ} \mathrm{C}$. Then, $5 \mathrm{ml}$ of buffer IS were added to the cell/bead preparation. Magnetically labelled cells were separated by placing the tube for $3 \mathrm{~min}$ onto the StrepMan magnet. Negative cell fraction was removed with the supernatant whereas the positive cell fraction was flushed off the tube by resuspension in $5 \mathrm{ml}$ buffer IS. Magnetic selection was repeated twice. Labelled cells were resuspended in $10 \mathrm{ml}$ of a $1 \mathrm{mM}$ D-biotin working solution and incubated for $10 \mathrm{~min}$ at room temperature. Then, tube was placed on the StrepMan magnet for $3 \mathrm{~min}$ and supernatant containing the target cell fraction was pipetted off the tube and transferred to another tube. The last step was repeated twice. Cells were centrifuged by $400 \mathrm{~g}$ for $10 \mathrm{~min}$ and resuspended in buffer. Using this procedure, CD4+ and CD25+ PBL were enriched. Then, CD127- PBL were separated by negative selection and $\mathrm{IFN} \gamma+\mathrm{PBL}$ were separated by subsequent positive selection, as described previously [7]. First, cells were incubated with CD127 monoclonal antibody (BD Biosciences, Heidelberg, Germany). Then, $\mathrm{CD} 4^{+} \mathrm{CD} 25^{+} \mathrm{CD} 127^{-}$were separated from $\mathrm{CD} 4^{+} \mathrm{CD} 25$ ${ }^{+} \mathrm{CD} 127^{-}$using streptavidin-coupled beads (Dynabeads Biotin Binder, Invitrogen, Dynal Oslo, Norway) according to the instructions of the manufacturer. Procedure was repeated using IFN $\gamma$ monoclonal antibody (BD Biosciences, Heidelberg, Germany, IFNY clone 4S.B3). Separated PBL were added to cell cultures.

\section{DNA isolation}

Genomic DNA of separated CD4+CD25+CD127-INF $\gamma+$ and CD4+CD25+CD127-INF $\gamma-T$ cells was extracted using the QIAamp cultured cells Mini Kit (Qiagen, Hilden, Germany) according to the protocol of the manufacturer. DNA was stored in Eppendorf tubes (Eppendorf, Hamburg, Germany) at $-20^{\circ} \mathrm{C}$.

\section{Bisulfite conversion of genomic DNA}

Bisulfite converts unmethylated cytosines to uracil, whereas methylated cytosines remain unreactive. After conversion of unmethylated cytosines to uracil by bisulfite treatment and subsequent PCR-mediated conversion of uracils to thymine, methylated and unmethylated alleles are predicted to differ in thermal stability because of their different $\mathrm{CpG}$ contents. Bisulfite conversion of genomic DNA was performed using the EZ DNA Methylation Kit (Zymo research, Freiburg, Germany) according to the manufacturer's instructions. CT Conversion Reagent powder was solved with $750 \mu \mathrm{l}$ water and $210 \mu \mathrm{l}$ M-Dilution buffer. $5 \mu \mathrm{l}$ of M-Dilution buffer was added to the isolated DNA samples. Total volume was adjusted to $50 \mu \mathrm{l}$ with water and mixed. CT Conversion Reagent and DNA samples were incubated separately in the dark at $37{ }^{\circ} \mathrm{C}$ for $15 \mathrm{~min}$. After incubation, $100 \mu \mathrm{l}$ of CT Conversion Reagent was added to each DNA sample. Samples were mixed and incubated in the dark at $50{ }^{\circ} \mathrm{C}$ for $12-16 \mathrm{~h}$. After incubation DNA samples were placed on ice for at least $10 \mathrm{~min}$. Then, DNA samples were loaded into a Zymo-Spin IC Column containing $400 \mu \mathrm{l} \mathrm{M}$-Binding buffer, mixed, and centrifuged at $10000 \mathrm{~g}$ for $30 \mathrm{~s}$. Additional $100 \mu \mathrm{l}$ of M-Wash buffer were added to the column and centrifuged at $10000 \mathrm{~g}$ for $30 \mathrm{~s}$. Then, another $200 \mu \mathrm{l}$ of M-Desulphonation buffer were added to the column, incubated at room temperature for $20 \mathrm{~min}$ and, finally, centrifuged at 10 $000 \mathrm{~g}$ for $30 \mathrm{~s}$. Further, $200 \mu \mathrm{l}$ of $\mathrm{M}$-Wash buffer were added to the column and centrifuged at $10000 \mathrm{~g}$ for 30 s. The procedure was repeated. Thereafter, the Zymo-Spin IC Column was placed into a clean $1.5 \mathrm{ml}$ microcentrifuge tube (Eppendorf), $15 \mu \mathrm{l}$ of M-Elution buffer were added to the column matrix, and samples were centrifuged at $10000 \mathrm{~g}$ for $30 \mathrm{~s}$. DNA was eluted in Eppendorf tubes and stored at $-20{ }^{\circ} \mathrm{C}$ for later use.

\section{Foxp3 TSDR DNA methylation analysis}

HRM analysis after bisulfite treatment identifies methylation variations in the Foxp3 gene. Bisulfite modified DNA was subjected to PCR according to the protocol for HRM analysis provided by the primer manufacturer (EpigenDx, Hopkinton, MA, USA). ADS3576 primers were used for the amplification of the promoter and 5'UTR region, and ADS783 primers for the amplification of the intron 1 TSDR of the Foxp3 gene. PCR was carried out in a $21 \mu \mathrm{l}$ total volume containing: $2.1 \mu \mathrm{l}$ PCR buffer, $0.27 \mu \mathrm{l} \mathrm{MgCl}_{2}, 0.42 \mu \mathrm{l}$ dNTPs, $1.05 \mu \mathrm{l}$ SYBR Green dye (EpigenDx), $1.26 \mu \mathrm{l}$ each of primers ADS783 
and ADS3576 (Human Foxp3 Methylation Panel, EpigenDx), $0.12 \mu \mathrm{l}$ Hot Start Taq polymerase (Qiagen), and $1.5 \mu \mathrm{l}$ of bisulfite-treated genomic DNA (concentration $5 \mathrm{ng} / \mu \mathrm{l})$. The amplification protocol with ADS783 primers consisted of incubation at $95{ }^{\circ} \mathrm{C}$ for $15 \mathrm{~min}$ followed by 45 cycles at $95{ }^{\circ} \mathrm{C}$ for $30 \mathrm{~s}, 62{ }^{\circ} \mathrm{C}$ for $30 \mathrm{~s}$ and $72{ }^{\circ} \mathrm{C}$ for $30 \mathrm{~s}$ with a final extension step at $72{ }^{\circ} \mathrm{C}$ for $5 \mathrm{~min}$. The amplification protocol with ADS3576 primer consisted of an incubation at $95^{\circ} \mathrm{C}$ for $15 \mathrm{~min}$ followed by 45 cycles at $95^{\circ} \mathrm{C}$ for $30 \mathrm{~s}, 59^{\circ} \mathrm{C}$ for $30 \mathrm{~s}$ and $72{ }^{\circ} \mathrm{C}$ for $30 \mathrm{~s}$ with a final extension step at $72{ }^{\circ} \mathrm{C}$ for $5 \mathrm{~min}$. Melting was performed from 60 to $90{ }^{\circ} \mathrm{C}$ at a melt rate of $1 \%$. Each sample was analyzed in triplicate. DNA methylation analysis and diagram generation were performed using real-time PCR software (Applied Biosystems 7500, Foster City, CA, USA).

\section{Standard curve}

7 commercially available standards with different proportions of methylated Foxp3 template DNA were used to estimate methylation status of the samples $(0,5,10,25,50$, 75, and $100 \%$ ) (Human Methylation Controls - Mix, EpigenDx). Templates were pretreated with bisulfite. For clarity, only 4 standards are depicted in the figures.

\section{Statistics}

All assays were repeated at least 3 times with PBL of different healthy controls. Representative test results and/or mean \pm SEM were depicted in the figures. For statistical analysis PASW Statistics program version 21 (IBM, Chicago, Illinois, USA) and Wilcoxon (Figs. 3, 4 and $6 \mathrm{a}$ ) and Student $\mathrm{t}$ test (Fig. 5) were used. P-values $\leq 0.05$ were considered significant. P-values of 0.056 were considered to show a trend.

\footnotetext{
Abbreviations

aTreg: Adaptive T regulator cell; Fab: Fragment antigen binding; HRM: High resolution melt; IL: Interleukin; MLC: Mixed lymphocyte culture; nTreg: Natural T regulator cell; PBL: Peripheral blood lymphocytes; PCR: Polymerase chain reaction; PMA: Phorbol 12-myristate 13-acetate; rIFNY: Recombinant interferon gamma; Tbet: T-box expressed in T cells; TCR: T cell receptor; Th1: T helper type 1; TSDR: Treg-specific demethylated region.
}

\section{Competing interests}

The authors declare that they have no competing interests.

\section{Authors' contributions}

VD designed the study and wrote the manuscript. GO made substantial contributions to conception and design as well as analysis and interpretation of data. KT and MA established Foxp3 TSDR methylation determination, have been involved in drafting the manuscript and revising it critically for important intellectual content. All authors have given final approval of the version to be published.

\section{Acknowledgements}

We would like to acknowledge the skilful technical assistance of Marion Miltz-Savidis, Silja Petersen-Novag, Lisa Michel, Martina Kutsche-Bauer, Regina Seemuth, and Anja Brüchig.
Received: 3 September 2014 Accepted: 31 July 2015

Published online: 13 August 2015

\section{References}

1. Daniel V, Wang H, Sadeghi M, Opelz G. Interferon-gamma producing regulatory $T$ cells as a diagnostic and therapeutic tool in organ transplantation. Int Rev Immunol. 2014;33(3):195-211.

2. Daniel V, Naujokat C, Sadeghi M, Weimer R, Renner F, Yildiz S, et al. Observational support for an immunoregulatory role of CD3+CD4+CD25 +IFN-gamma+ blood lymphocytes in kidney transplant recipients with good long-term graft outcome. Transpl Int. 2008;21(7):646-60.

3. Dominguez-Villar M, Baecher-Allan CM, Hafler DA. Identification of T helper type 1-like, Foxp3+ regulatory T cells in human autoimmune disease. Nat Med. 2011;17(6):673-5.

4. McClymont SA, Putnam AL, Lee MR, Esensten JH, Liu W, Hulme MA, et al. Plasticity of human regulatory $T$ cells in healthy subjects and patients with type 1 diabetes. J Immunol. 2011;186(7):3918-26.

5. Daniel V, Sadeghi M, Wang H, Opelz G. CD4+CD25+Foxp3+IFN-gamma+ human induced $T$ regulatory cells are induced by interferon-gamma and suppress alloresponses nonspecifically. Hum Immunol. 2011;72(9):699-707.

6. Daniel V, Sadeghi M, Wang H, Opelz G. CD4(+)CD25(+)Foxp3(+)IFNgamma(+)CD178(+) human induced Treg (iTreg) contribute to suppression of alloresponses by apoptosis of responder cells. Hum Immunol. 2013;74(2):151-62.

7. Daniel V, Sadeghi M, Wang H, Opelz G. In-vitro inhibition of IFNgamma+ iTreg mediated by monoclonal antibodies against cell surface determinants essential for iTreg function. BMC Immunol. 2012;13:47.

8. Daniel V, Sadeghi M, Wang H, Opelz G.

CD4(+)CD25(+)Foxp3(+)IFNgamma(+) Treg are immunosuppressive in vitro and increase with intensity of the alloresponse in pretransplant MLC. Transpl Immunol. 2012;27(2-3):114-21.

9. Floess S, Freyer J, Siewert C, Baron U, Olek S, Polansky J, et al. Epigenetic control of the foxp3 locus in regulatory T cells. PLoS Biol. 2007;5(2), e38.

10. Polansky JK, Kretschmer K, Freyer J, Floess S, Garbe A, Baron U, et al. DNA methylation controls Foxp3 gene expression. Eur J Immunol. 2008;38(6):1654-63.

11. Amsen $D$, Spilianakis CG, Flavell RA. How are $T(H) 1$ and $T(H) 2$ effector cells made? Curr Opin Immunol. 2009;21(2):153-60.

12. Thornton AM, Korty PE, Tran DQ, Wohlfert EA, Murray PE, Belkaid Y, et al. Expression of Helios, an Ikaros transcription factor family member, differentiates thymic-derived from peripherally induced Foxp3+ T regulatory cells. J Immunol. 2010;184(7):3433-41.

13. Himmel ME, MacDonald KG, Garcia RV, Steiner TS, Levings MK. Helios+ and Helios- cells coexist within the natural FOXP3 + T regulatory cell subset in humans. J Immunol. 2013;190(5):2001-8.

14. Hall BM, Tran GT, Verma ND, Plain KM, Robinson CM, Nomura M, et al. Do Natural T Regulatory Cells become Activated to Antigen Specific T Regulatory Cells in Transplantation and in Autoimmunity? Front Immunol. 2013;4:208.

15. Verma ND, Hall BM, Plain KM, Robinson CM, Boyd R, Tran GT, et al. Interleukin-12 (IL-12p70) promotes induction of highly potent Th1-Like CD4(+)CD25(+) T regulatory cells that inhibit allograft rejection in unmodified recipients. Front Immunol. 2014;5:190.

16. Feng T, Cao AT, Weaver CT, Elson CO, Cong Y. Interleukin-12 converts Foxp3 + regulatory $T$ cells to interferon-gamma-producing Foxp3+ T cells that inhibit colitis. Gastroenterology. 2011;140(7):2031-43.

17. Esposito M, Ruffini F, Bergami A, Garzetti L, Borsellino G, Battistini L, et al. IL-17- and IFN-gamma-secreting Foxp3+ T cells infiltrate the target tissue in experimental autoimmunity. J Immunol. 2010;185(12):7467-73.

18. O'Connor RA, Leech MD, Suffner J, Hammerling GJ, Anderton SM. Myelinreactive, TGF-beta-induced regulatory $T$ cells can be programmed to develop Th1-like effector function but remain less proinflammatory than myelin-reactive Th1 effectors and can suppress pathogenic T cell clonal expansion in vivo. J Immunol. 2010;185(12):7235-43.

19. Zhou X, Bailey-Bucktrout SL, Jeker LT, Penaranda C, Martinez-Llordella M, Ashby $M$, et al. Instability of the transcription factor Foxp3 leads to the generation of pathogenic memory T cells in vivo. Nat Immunol. 2009;10(9):1000-7.

20. Oldenhove G, Bouladoux N, Wohlfert EA, Hall JA, Chou D, Dos Santos L, et al. Decrease of Foxp3+ Treg cell number and acquisition of effector cell phenotype during lethal infection. Immunity. 2009;31(5):772-86. 
21. Duarte JH, Zelenay S, Bergman ML, Martins AC, Demengeot J. Natural Treg cells spontaneously differentiate into pathogenic helper cells in Iymphopenic conditions. Eur J Immunol. 2009;39(4):948-55.

22. Tsuji M, Komatsu N, Kawamoto S, Suzuki K, Kanagawa O, Honjo T, et al. Preferential generation of follicular B helper T cells from Foxp3+ T cells in gut Peyer's patches. Science. 2009:323(5920):1488-92.

23. Baban B, Chandler PR, Sharma MD, Pihkala J, Koni PA, Munn DH, et al. IDO activates regulatory $T$ cells and blocks their conversion into Th17-like T cells. J Immunol. 2009;183(4):2475-83.

24. Mellor AL, Munn DH. Physiologic control of the functional status of Foxp3+ regulatory T cells. J Immunol. 2011;186(8):4535-40.

25. Koch MA, Tucker-Heard G, Perdue NR, Killebrew JR, Urdahl KB, Campbell DJ. The transcription factor $\mathrm{T}$-bet controls regulatory $\mathrm{T}$ cell homeostasis and function during type 1 inflammation. Nat Immunol. 2009;10(6):595-602.

26. Koch MA, Thomas KR, Perdue NR, Smigiel KS, Srivastava S, Campbell DJ. T-bet(+) Treg cells undergo abortive Th1 cell differentiation due to impaired expression of IL-12 receptor beta2. Immunity. 2012;37(3):501-10.

27. Sakaguchi S, Miyara M, Costantino CM, Hafler DA. FOXP3+ regulatory T cells in the human immune system. Nat Rev Immunol. 2010;10(7):490-500.

28. Edozie FC, Nova-Lamperti EA, Povoleri GA, Scotta C, John S, Lombardi G, et al. Regulatory T-cell therapy in the induction of transplant tolerance: the issue of subpopulations. Transplantation. 2014;98(4):370-9.

\section{Submit your next manuscript to BioMed Central and take full advantage of:}

- Convenient online submission

- Thorough peer review

- No space constraints or color figure charges

- Immediate publication on acceptance

- Inclusion in PubMed, CAS, Scopus and Google Scholar

- Research which is freely available for redistribution 